\title{
水泥基材料离子迁移过程的可视化与定量分析
}

\author{
董必钦，孔 钟，吴育盛，洪舒贤 \\ 深圳大学土木与交通工程学院，广东省滨海土木工程耐久性重点实验室，广东深圳 518060
}

摘 要: 氯离子的侵蚀是引起滨海混凝土钢筋锈蚀的关键因素之一. 为探索离子在水泥基材料中的原 位迁移过程，利用 X 射线计算机断层扫描（X-ray computed tomography，XCT) 技术，以碘化物为示踪剂， 对掺有粉煤灰的水泥基材料的离子迁移过程进行无损分析. 结果表明，XCT 技术可以对离子在水泥基材料 中的迁移过程进行无损、可视化跟踪，并能精确定量离子在样品内的浓度分布. 将 XCT 与滴定法分别测得 的离子浓度进行对比, 证明了 XCT 测试结果的准确性.

关键词：建筑材料；水泥；离子迁移；X 射线断层扫描技术；无损检测；可视化分析

中图分类号: TU528 文献标志码: A doi: 10.3724/SP. J. 1249.2021.04387

\section{Visualization and quantitative research of ion migration process in cement-based materials}

\author{
DONG Biqin, KONG Zhong, WU Yusheng, and HONG Shuxian \\ College of Civil and Transportation Engineering, Guangdong Province Key Laboratory of Durability for Marine Civil Engineering, \\ Shenzhen University, Shenzhen 518060, Guangdong Province, P. R. China
}

\begin{abstract}
The erosion of chloride ions is one of the key factors of concrete reinforcement corrosion in coastal area. In order to explore the in-situ migration process of ions in cement-based materials, the $\mathrm{X}$-ray computed tomography (XCT) is used to analyze the migration process using iodide as tracer in cement-based materials mixed with fly ash. The results show that XCT technology can track the ion migration process in cement-based materials non-destructively and visually, and accurately quantify the concentration distribution of ions in the specimens. And the accuracy of XCT test results is proved by comparing the ion concentration measured by XCT and titration method.
\end{abstract}

Key words: building materials; cement; ion migration; X-ray computed tomography; nondestructive testing; visualization analysis

氯离子侵蚀是滨海环境下引起钢筋锈蚀, 导致 混凝土结构耐久性损伤的主要原因 ${ }^{[1-2]}$. 研究水泥 基材料中氯离子的传输规律, 有助于深人分析钢筋 混凝土的锈蚀机理，对提高钢筋混凝土结构的耐久 性具有十分重要的意义 ${ }^{[3-4]}$. 测定材料中的氯离子 浓度最常用的方法是电位滴定法 ${ }^{[5-7]}$ 和 $X$ 射线苂光 光谱 (X-ray fluorescence spectrometer, XRF) 技
术 $^{[8-9]}$ ，但滴定法和 XRF 法都需要破坏样品，是有 损测试, 无法做到对同一样品的持续监测. 电化学 阻抗谱( electrochemical impedance spectroscopy, EIS) 可用来测量阻抗等电参数的变化, 达到不破坏样品 的目的 ${ }^{[10-12]}$, 但准确度不高, 而且无法提供直观可 视化结果. 近年来，中子射线照相技术已被用于无 损检测混凝土中离子扩散过程, 但中子成像对氢原

Received: 2020-05-29; Accepted: 2020-11-14; Online (CNKI) : 2021-06-11

Foundation: National Natural Science Foundation of China (51727813, 51925805)

Corresponding author: Associate professor HONG Shuxian. E-mail: sxhong@ szu.edu.cn

Citation: DONG Biqin, KONG Zhong, WU Yusheng, et al. Visualization and quantitative research of ion migration process in cement-based materials $[\mathrm{J}]$. Journal of Shenzhen University Science and Engineering, 2021, 38(4): 387-392. (in Chinese) 
子敏感, 不能测量某些离子, 如建筑材料中的顺磁 离子 ${ }^{[13]}$. X 射线计算机断层扫描 (X-ray computed tomography, XCT) 技术作为一种方便有效的无损检 测方法, 可跟踪水泥基材料中氯离子的迁移过 程 $^{[14]}$.

$\mathrm{XCT}$ 是一种利用三维图像对测试样品内部进行 可视化研究的无损检测技术 ${ }^{[15]}$. 利用一系列二维 投影结果将扫描图像重建为三维断层成像图像, CT 值的取值代表材料对 $\mathrm{X}$ 射线光子的吸收程度, 主要 由材料的原子序数和密度决定. 然而氯离子与水泥 基材料的线吸收系数比较接近, 在水泥中的传输过 程难以直接用图像显示. 碘离子和氯离子的大小相 似, 且同为卤族元素, 使得碘化物可成为水泥基材 料中离子迁移研究的良好示踪剂 ${ }^{[17]}$. 本研究使用 $\mathrm{NaI}$ 作为造影剂或示踪剂 ${ }^{[18]}$, 利用 XCT 技术检测 离子在水泥基材料中的迁移行为, 可视化、定量表 征氯离子在材料中的分布特征. 首先, 研究碘离子 与氯离子的迁移同步性. 然后, 利用 XCT 图像处理
方法, 对氯离子在水泥基材料中的迁移过程进行可 视化和定量分析, 包括对图像进行了射束硬化伪影 校正, 对灰度值进行归一化处理, 并且利用外部标 定结果得到离子的浓度分布. 最后, 䢃开样品, 利 用滴定法测得迁移深度及浓度分布, 对 XCT 处理结 果进行验证.

\section{1 实验}

\section{1 试块制备}

本研究采用英德海螺有限责任公司烧制的海螺 牌 P. O. 42.5 普通硅酸盐水泥, 水泥和粉煤灰的化 学组成见表 1 . 样品为掺人 $10 \%$ (质量分数) 粉煤 灰的水泥净浆制备试件, 水灰比为 0.4 . 圆柱体试 样高为 $25 \mathrm{~mm}$, 直径为 $10 \mathrm{~mm}$, 经过养护成型后拆 模, 并放人水泥养护室, 相对湿度 $\geqslant 95 \%$, 温度 $(20 \pm 3)^{\circ} \mathrm{C}$, 养护 $28 \mathrm{~d}$, 制备过程参考 GB 1752007.

表 1 水泥和粉煤灰的主要化学成分

Table 1 Main chemical composition of cement and fly ash

\begin{tabular}{rcccccccc}
\hline 试样 & $\omega(\mathrm{CaO})$ & $\omega\left(\mathrm{SiO}_{2}\right)$ & $\omega\left(\mathrm{Al}_{2} \mathrm{O}_{3}\right)$ & $\omega\left(\mathrm{Fe}_{2} \mathrm{O}_{3}\right)$ & $\omega(\mathrm{MgO})$ & $\omega\left(\mathrm{SO}_{3}\right)$ & $\omega\left(\mathrm{K}_{2} \mathrm{O}\right)$ & $\omega\left(\mathrm{Na}_{2} \mathrm{O}\right)$ \\
\hline 水泥 & 64.2 & 21.0 & 4.2 & 2.9 & 1.7 & 4.1 & 0.7 & 0.2 \\
粉煤灰 & 14.2 & 43.1 & 19.7 & 8.5 & 1.7 & 1.7 & 1.2 & 3.5 \\
\hline
\end{tabular}

\section{2 通电加速离子迁移试验}

样品在经过 $28 \mathrm{~d}$ 的养护后, 用饱和氢氧化钙溶 液进行饱和处理, 以满足离子通电加速迁移的需 要. 另外, 对所有圆柱试样的侧面进行封涂环氧树 脂密封处理, 确保离子是一维单向迁移. 将试件夹 于正、负极溶液室中间，负极溶液采用浓度为 1.8 $\mathrm{mol} / \mathrm{L}$ 的 $\mathrm{NaCl}$ 或 $\mathrm{NaI}$ 溶液, 正极溶液为 $0.3 \mathrm{~mol} / \mathrm{L}$ 的 $\mathrm{NaOH}$ 溶液, 试验装置示意图见图 1. 采用恒压 $30 \mathrm{~V}$ 的直流电源加速离子迁移. 为研究氯离子和硔 离子的迁移同步性，样品每次通电时间间隔为 $1 \mathrm{~h}$, 时间到后将样品取出, 总共通电 6 次 $\left(t_{1} \sim t_{6}\right)$. 离 子迁移试验按照快速氯离子迁移试验标准 $(\mathrm{GB} / \mathrm{T}$ 50082-2009) 进行.

\subsection{XCT 拍摄}

为清晰地可视化表征离子在水泥试样中的迁移 情况, 本研究以碘离子作为 XCT 图像增强剂, XCT 的型号为 XRadia Micro XCT- 400. 试验射线源的电 压为 $69 \mathrm{kV}$, 电流为 $100 \mu \mathrm{A}$, 放大倍数为 0.39 , 曝 光时间 $3 \mathrm{~s}$, 光源距离样品 $70 \mathrm{~mm}$, 探测器距离样品 $65.0006 \mathrm{~mm}$, 像素大小 $35 \mu \mathrm{m}$. 重构图像矩阵为

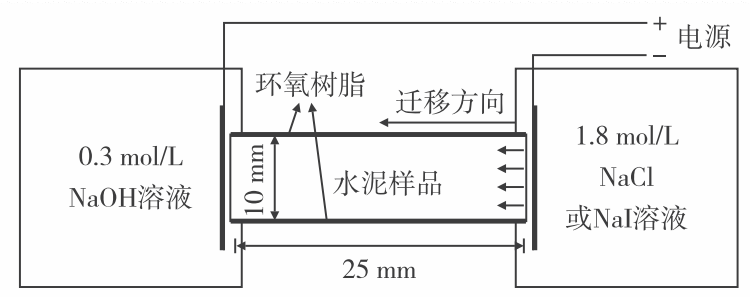

图 1 加速离子迁移装置图

Fig. 1 Schematic diagram of accelerated ion migration

$1024 \times 1024 \times 1000$. 共获得 7 次 XCT 扫描结果， 包含迁移前的 1 次基准测试 $\left(t_{0}\right)$ 和 6 次以 $1 \mathrm{~h}$ 为间 隔的测试 $\left(t_{1} \sim t_{6}\right)$.

\section{4 离子迁移深度及浓度验证}

为验证 XCT 测量获得的迁移深度及离子浓度, 将 4 个样品进行了相同的迁移试验. 在每个 XCT 测 试点 $\left(t_{1} \sim t_{6}\right)$, 将 1 个样品䢃开喷酒显色剂测量迁 移深度 ${ }^{[19-20]}$. 将另外 3 个样品以为间隔沿试件长度 进行切割, 采用滴定法测定离子浓度 ${ }^{[21]}$, 以验证 XCT 试验得到的迁移深度和浓度分布. 


\section{2 试验结果及分析}

\section{1 磑离子作为迁移的表征离子验证}

本研究采用实验的方法研究氯离子和碘离子在 水泥基材料中的迁移同步性. 试验中，阴极槽为相 同浓度的氯化钠或碘化钠溶液，迁移一段时间后， 用自动电位滴定仪测得两种离子的浓度分布. 样品 中氯离子和碘离子的浓度分布见图 2 ，从图 2 可见， 两种离子在样品内的分布规律相似，同一深度氯离 子总体比碘离子浓度高 $3.1 \%$, 且基本所有结果均 在 $95 \%$ 置信区间内，可以看出两种离子浓度分布在 整体变化上趋于相同，氯离子与磑离子具有相似的 传输特性. 刘军等 ${ }^{[19]}$ 也研究发现碘离子具有与氯 离子相似的传输规律. 所以, 可采用碘离子代替氯 离子，利用 XCT 测试水泥基材料的离子迁移能力.

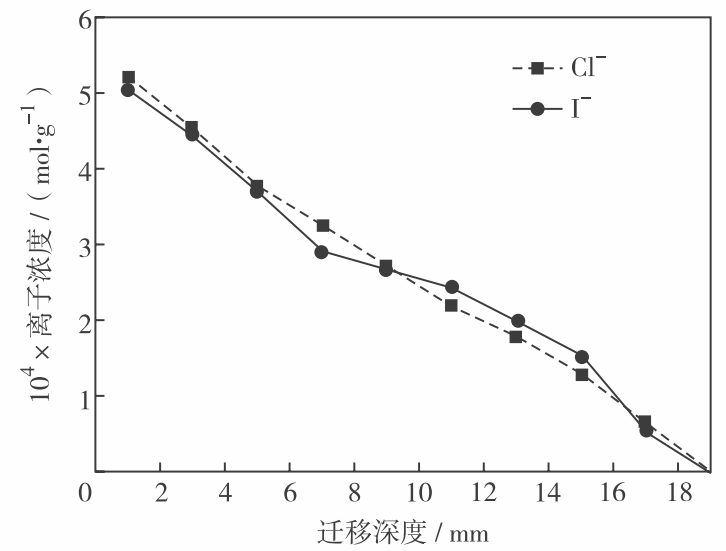

(a) 离子浓度随深度的变化

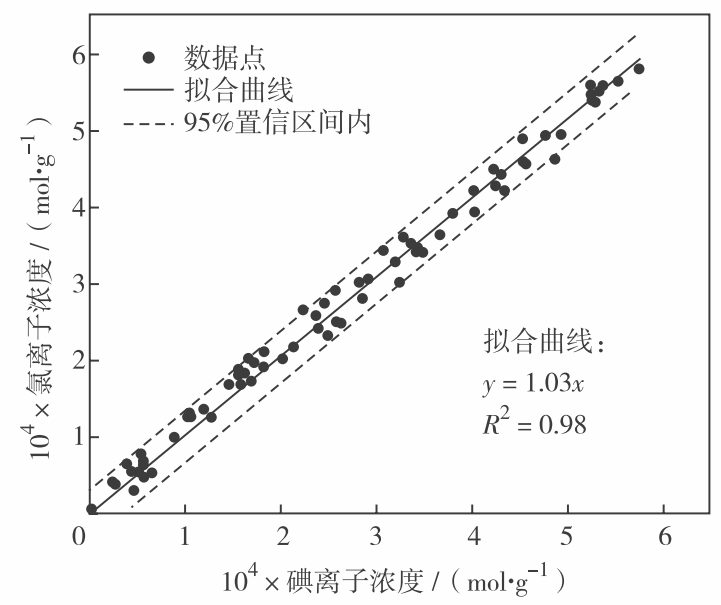

(b) 碘离子和氯离子浓度的对应关系

图 2 样品中氯离子和磑离子的浓度分布

Fig. 2 Comparison of concentration distribution of chloride and iodine ion in samples

\subsection{XCT 数据分析}

XCT 数据处理过程 ${ }^{[22]}$ 为: 首先, 对原始 XCT 投影图像进行重构得到三维图像, 对射束硬化效应 进行校正后, 沿高度方向计算水泥样品的平均灰度 值; 然后，利用不含离子部分进行直方图评估，对 CT 值进行归一化处理; 最后，利用外部标定曲线 对离子浓度进行标定, 定量化离子浓度分布.

\subsection{1 射束硬化校正}

首先对原始切片进行重构获得三维图像. 在纵 向截面图中, 碘离子的 $\mathrm{X}$ 射线衰减系数高于水泥 的, 所以含有碘离子的部分图像更亮. 由于射束硬 化效应会在图像边缘存在伪影, 如图 3 (a) 在样品 底部边缘相较中间部分更亮, 即存在环状伪影. 根 据 KRUMM 等 ${ }^{[22-23]}$ 的图像修正理论，使用 Sobel 滤 波器进行图像分割以区分不同材料，对每层扫描图 像分别进行校正，然后对图像进行重构，可以得到 射束硬化校正后的图像. 图 3 (b) 为射束硬化校正 后的 XCT 图像，可以看出，矫正后图像在横向分布 较均匀, 且能够清楚看出离子的迁移界线. 而且由 于碘离子浓度的差异, XCT 图的灰度值沿试样高度 方向自下往上逐渐递减，图像灰度的变化代表离子 含量的变化. 然而要想准确获得样品内部离子浓度 分布, 还需要进一步的分析.

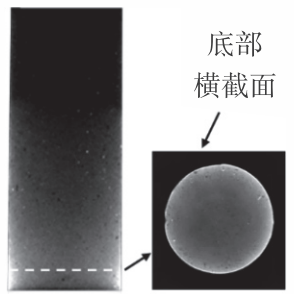

(a) 校正前

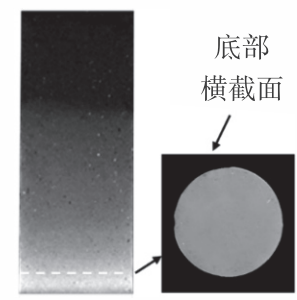

(b) 校正后
图 3 射束硬化校正前后 XCT 图像

Fig. 3 Section of XCT image before and after beam hardening correction

\subsubsection{CT 值归一化}

在重构数据中， CT 值与有效衰减系数成线性 关系，与样品中不同的材料对应，图像灰度的变化 意味着样品材料的变化. 然而, 由于 $\mathrm{X}$ 射线源能量 在不同的测量中不同，即使在相同的测试参数下， CT 值与材料衰减系数的对应关系也不是固定的. 为了比较不同 XCT 试验的结果, CT 值需要进行归 一化. HONG 等 ${ }^{[24]}$ 提出的 CT 值归一化方法是在射 束硬化矫正后，计算每个切片的平均 CT 值，获得 整个样品的平均 CT 值曲线, 然后选择不含碘离子 
部分的 CT 值作为参考. 因为该部分 CT 值理论上是 不变的, 并且与 $t_{0}$ 时的 CT 值相同. 将参考值与 $t_{0}$ 时的 CT 值调整一致，曲线其他部分的 CT 值也会归 为统一尺度. 图 4 给出了 XCT 数据归一化前后的纵 向截面对比结果. 由图 4 可见，经过图像处理后， 顶部不含磑离子部分的图像亮度一致. 基于平均灰 度值法，图 5 展示了应用 XCT 技术可视化追踪离子 迁移深度的变化过程.

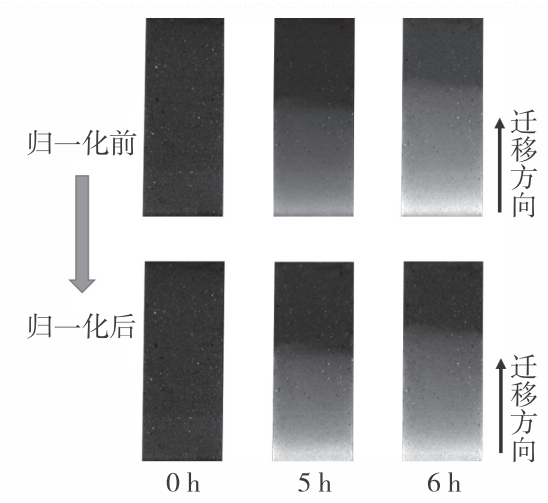

图 4 不同时间 CT 值归一化前后 XCT 数据的纵向截面

Fig. 4 Radial cross section of XCT data after beam hardening correction at different times and before $\mathrm{CT}$ value normalization

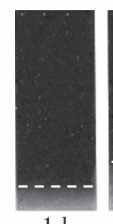

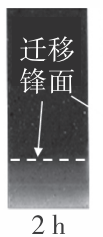
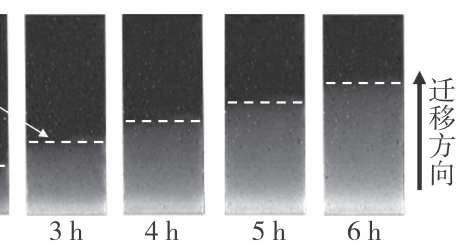

图 5 试样中离子迁移深度的二维变化

Fig. 5 The 2D evolution process of iron migration in cement paste

\subsubsection{CT 值标定}

灰度值归一化后，计算每个切片的平均 CT 值. 图 6 为不同迁移时间下的平均 CT 值分布. CT 值的 减少与碘离子浓度的减少有关. 因此可以根据 CT 值的变化计算出样品中离子浓度的变化.

然而, 要最终得到离子浓度曲线, 还需进一步 标定. 由于在 XCT 测试中使用了碘化钠作为示踪 剂, CT 值与碘离子的浓度呈线性关系, $\mathrm{X}$ 射线束 穿透样品的衰减可用 Beer-Lambert 定律 ${ }^{[22]}$ 表示:

$$
I=I_{0} \mathrm{e}^{-\mu x}
$$

其中, $I_{0}$ 和 $I$ 分别是 $\mathrm{X}$ 射线束衰减前后的强度; $x$ 是 射线穿过材料的距离; $\mu$ 是样品的线性衰减系数. 在获得已知碘化钠浓度的校准样品 XCT 图像后, 对

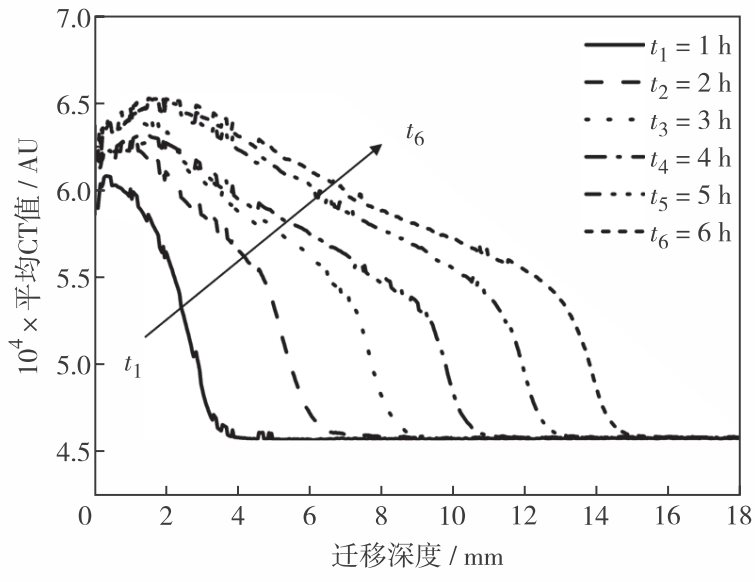

图 6 样品平均 CT 值曲线

Fig. 6 The average CT number profiles

图像进行射束硬化校正和归一化，计算平均灰度 值. 图 7 建立了 CT 值与离子浓度间的线性关系. 将 CT 值转换为浓度数据, 得到如图 8 的离子浓度 分布. 离子浓度随样品深度的增加而降低，由拐点 可以确定迁移的深度.

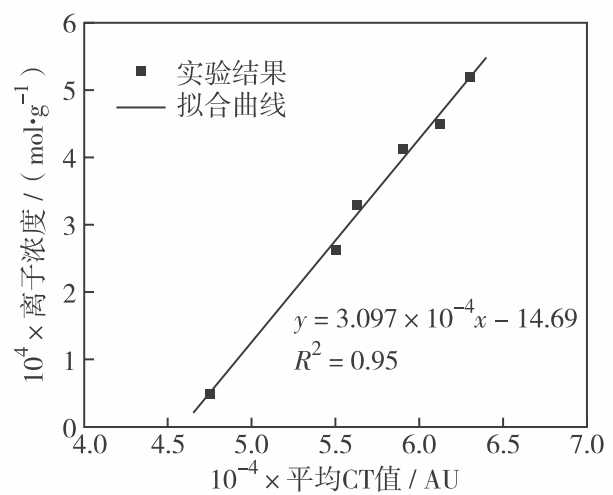

图 7 离子浓度与平均 CT 值的相关性

Fig. 7 Correlation between ion concentration and average CT number profiles

\section{2 验证 XCT 测得的迁移前缘高度}

除了从图 5 可以直观看出离子迁移深度外, 利 用图 8 离子浓度曲线的拐点也可以确定迁移深度, 而且更为精确. 为了验证 XCT 测量的迁移高度, 将 参考样品䢃开喷酒显色剂, 得到离子迁移深度如图 9. 由图 9 可知，迁移深度与时间的平方根有良好 的线性关系.

\section{3 验证 XCT 测得的离子浓度}

为了验证 XCT 测试测得的离子浓度梯度，用滴 定法测定碘化物的含量. 迁移 $6 \mathrm{~h}$ 后滴定和 XCT 测 得的结果如图 10. 由图 10 可见, 可以看出两种方 法的测试结果具有较好的相似性. 


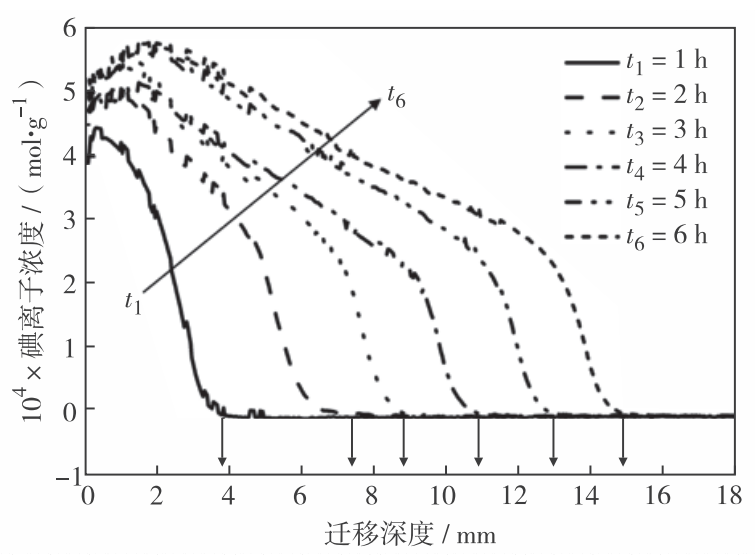

图 8 利用 CT 值增量标定的离子浓度分布曲线

Fig. 8 Ion concentration distribution curve calibrated by incremental $\mathrm{CT}$ value

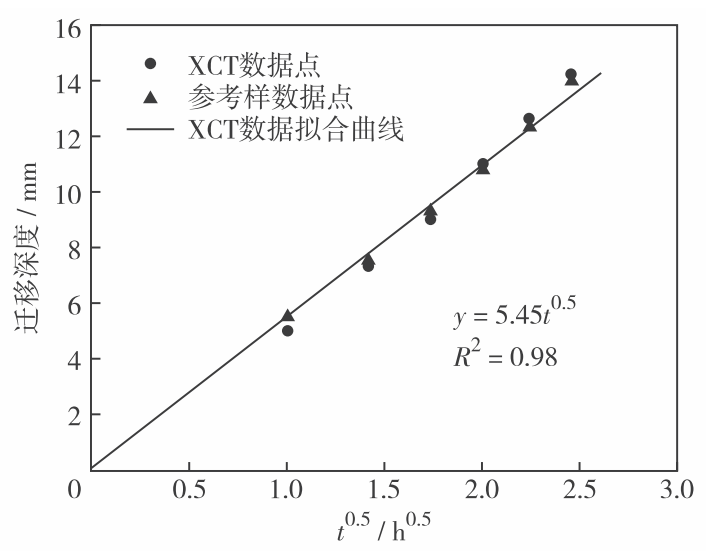

图 9 参考样和 XCT 试样的迁移深度与 时间平方根的关系

Fig. 9 Height of migration front versus the square root of time for the reference specimens and the XCT test specimen

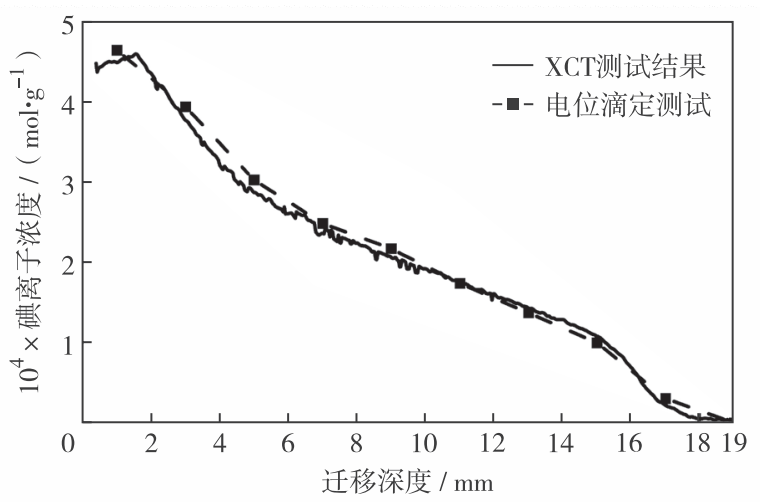

图 $10 \mathrm{XCT}$ 测试与电位滴定对比

Fig. 10 Comparison between XCT test and potentiometric titration

\section{3 结 论}

应用 XCT 技术对水泥基材料离子迁移过程进行 可视化和定量分析, 可知: (1) 碘离子与氯离子在 水泥基材料中的迁移过程是同步的，因此, $\mathrm{NaI}$ 可 以作为 XCT 示踪剂来标记离子在水泥基材料中的迁 移过程; (2) 采用 XCT 数据处理方法对 CT 图像进行 伪影校正, 并将不同测量值的图像归一化处理, 可 以可视化、定量表征离子迁移过程; (3) 根据 XCT 测试得到的离子浓度曲线和迁移锋面位置, 与水泥 基材料的预期迁移性能具有一致性.

\section{基金项目：国家自然科学基金资助项目 $(51727813 ， 51925805)$ 作者简介: 董必钦 $(1973-)$, 深圳大学教授. 研究方向: 混凝土 耐久性与功能建材. E-mail: incise@ szu.edu.cn \\ 引文: 董必钦, 孔 钟, 吴育盛, 等. 水泥基材料离子迁移过 程的可视化与定量分析 $[\mathrm{J}]$. 深圳大学学报理工版, $2021,38(4)$ : 387-392.}

\section{参考文献 / References :}

[ 1 ] WANG Yunyao, SHUI Zhonghe, GAO Xu, et al. Understanding the chloride binding and diffusion behaviors of marine concrete based on Portland limestone cementalumina enriched pozzolans [ J ]. Construction and Building Materials, 2019, 198 : 207-217.

[ 2 ] ZHANG Yun, ZHOU Xiaoyun, ZHAO Jing, et al. Time dependency and similarity of decay process of chloride diffusion in concrete under simulated marine tidal environment $[\mathrm{J}]$. Construction and Building Materials, 2019,205 : 332-343.

[3] 史才军, 元 强, 邓德华, 等. 混凝土中氯离子迁移特 征的表征 $[\mathrm{J}]$. 硅酸盐学报, 2007, 35(4) : 522-530.

SHI Caijun, YUAN Qiang, DENG Dehua, et al. Test methods for the transport of chloride ion in concrete $[\mathrm{J}]$. Journal of the Chinese Ceramic Society, 2007, 35 (4): 522-530. (in Chinese)

[ 4 ] 吴建华, 张亚梅. 混凝土抗氯离子渗透性试验方法综 述 $[\mathrm{J}]$. 混凝土, 2009(2): 38-41.

WU Jianhua, ZHANG Yamei. Overview of test methods of chloride ion penetration in concrete $[\mathrm{J}]$. Concrete, 2009 (2) : 38-41. (in Chinese)

[5]陈天星. 电位滴定法测定混凝土外加剂氯离子含量中 的问题与改良方法探讨 $[\mathrm{J}]$. 建材与装饰, 2016(14)： 88-89.

CHEN Tianken. The problems and improvement methods of potentiometric titration in the determination of chloride ion content of concrete admixture are discussed $[\mathrm{J}]$. 
Building Materials and Decoration, 2016(14) : 88-89. (in Chinese)

[6 ] LIU Jun, OU Guangfeng, QIU Qiwei, et al. Chloride transport and microstructure of concrete with/without fly ash under atmospheric chloride condition $[\mathrm{J}]$. Construction and Building Materials, 2017, 147 : 493-501.

[ 7 ] 高天霞. 电位滴定法测定混凝土外加剂氯离子含量不 确定度分析研究 $[\mathrm{J}]$. 广东建材, 2014, 30（8)：1719.

GAO Tianxia. Determination of chloride ion content uncertainty of concrete admixture by potentiometric titration method $[\mathrm{J}]$. Guangdong Building Materials, 2014, 30 (8) : 17-19. (in Chinese)

[ 8 ] MORADLLO M K, SUDBRINK B, HU Q, et al. Using micro X-ray fluorescence to image chloride profiles in concrete $[\mathrm{J}]$. Cement and Concrete Research, 2016, 92 : 128-141.

[ 9 ] RYDBERG J. Wavelength dispersive X-ray fluorescence spectroscopy as a fast, non-destructive and cost-effective analytical method for determining the geochemical composition of small loose-powder sediment samples $[\mathrm{J}]$. Journal of Paleolimnology, 2014, 52(3) : 265-276.

[10] MONTEMOR M F, SIMOES A M P, SALTA M M. Effect of fly ash on concrete reinforcement corrosion studied by EIS [ J ] . Cement and Concrete Composites, 2000, 22 (3) : 175-185

[11] DONG Biqin, WU Yusheng, TENG Xiaojuan, et al. Investigation of the $\mathrm{Cl}^{-}$migration behavior of cement materials blended with fly ash or/and slag via the electrochemical impedance spectroscopy method $[\mathrm{J}]$. Construction and Building Materials, 2019, 211: 261270.

[12] LOCHE J M, AMMAR A, DUMARGUE P. Influence of the migration of chloride ions on the electrochemical impedance spectroscopy of mortar paste $[\mathrm{J}]$. Cement and Concrete Research, 2005, 35(9) : 1797-1803.

[13] DERLUYN H, GRIFFA M, MANNES D, et al. Characterizing saline uptake and salt distributions in porous limestone with neutron radiography and $\mathrm{X}$-ray microtomography $[\mathrm{J}]$. Journal of Building Physics, 2013, 36 (4) : 353-374.

[14] TIAN Ye, CHEN Changchang, JIN Nanguo, et al. An investigation on the three-dimensional transport of chloride ions in concrete based on X-ray computed tomography technology $[\mathrm{J}]$. Construction and Building Materials, $2019,221: 443-455$.
[15] YANG Yonggan, ZHANG Yunsheng, SHE Wei, et al. In situ observing the erosion process of cement pastes exposed to different sulfate solutions with X-ray computed tomography $[\mathrm{J}]$. Construction and Building Materials, 2018, 176: 556-565.

[16] MORADLLO K M, HU Qinang, LEY M T. Using X-ray imaging to investigate in-situ ion diffusion in cementitious materials $[\mathrm{J}]$. Construction and Building Materials, 2017, 136: 88-98.

[17] SONG Zijian, JIANG Linhua, CHU Hongqiang, et al. Evaluation research on applicability of rapid iodide migration test $[\mathrm{J}]$. Journal of Wuhan University of Technology-Mater Science, 2014, 29(2) : 329-333.

[18 ] DEBOODT T, WILDENSCHILD D, Ideker J H, et al. Use of iodine for improving phase quantification using $\mathrm{X}$-ray tomography $[\mathrm{J}]$. Cement and Concrete Research, 2019, 116: 102-112.

[19] 刘 军. 基于碘离子传输特征的混凝土渗透性评价方 法研究 $[D]$. 长沙: 中南大学, 2013.

LIU Jun. Permeability evaluation method of concrete Based on the transport characteristics of iodide ions [ D ]. Changsha: Central South University, 2013. (in Chinese)

[20 ] HE Fuqiang, SHI Caijun, YUAN Qiang, et al. Calculation of chloride concentration at color change boundary of $\mathrm{AgNO}_{3}$ colorimetric measurement $[\mathrm{J}]$. Cement and Concrete Research, 2011, 41(11) : 1095-1103.

[21 ] JGJ/T 322-2013 混凝土中氯离子含量检测规程 $[\mathrm{S}$ ]. JGJ/T 322-2013 Technical specification for test of chloride ion content in concrete $[\mathrm{S}]$. (in Chinese)

[22] KRUMM M, KASPERL S, FRANZ M. Reducing nonlinear artifacts of multi-material objects in industrial 3D computed tomography $[\mathrm{J}]$. Nondestructive Testing and Evaluation International, 2008, 41: 242-251.

[23] FANG Guohao, DING Weijian, LIU Yuqing, et al. Identification of corrosion products and 3D distribution in reinforced concrete using X-ray micro computed tomography $[\mathrm{J}]$. Construction and Building Materials, 2019, 207: 304-315.

[24] HONG Shuxian, QIN Shaofeng, YAO Wanqiong, et al. Visualized tracing of capillary absorption process in cementitious material based on X-ray computed tomography [J]. Cement and Concrete Composites, 2020, 107, 103487.

【中文责编: 坪 梓; 英文责编: 之 聿】 